\title{
Are Children Most of the Submerged Part of SARS-CoV-2 Iceberg?
}

\author{
Stefano Passanisi ${ }^{*}$, Fortunato Lombardo, Giuseppina Salzano and Giovanni Battista Pajno \\ Department of Human Pathology in Adult and Developmental Age Gaetano Barresi, University of Messina, Messina, Italy
}

Keywords: children, coronavirus, COVID-19, Italy, outbreak, pandemic, transmission

\section{INTRODUCTION}

Since the end of 2019, a novel coronavirus disease 2019 (COVID-19) caused by a novel coronavirus, severe acute respiratory syndrome coronavirus 2 (SARS-CoV-2) has been developing in Wuhan, Hubei Province, China (1). In very few months it has spread all over the world and the World Health Organization on March 11, 2020 declared COVID-19 a pandemic.

Italy is currently one of the most affected countries in Europe. At the time of this publication, 120,290 cases of SARS-CoV-2 infection have been detected. Median age of infected patients is 62 years. Interestingly, only $1.5 \%$ of patients diagnosed with SARS-CoV-2 are aged $0-18$ years.

OPEN ACCESS

Edited by:

Christoph Aebi,

University Children's Hospital

Bern, Switzerland

Reviewed by:

Richard Fabian Schumacher,

Children's Hospital, ASST of the

Brescia Spedali Civili, Italy

*Correspondence:

Stefano Passanisi

spassanisi87@gmail.com

Specialty section:

This article was submitted to

Pediatric Infectious Diseases,

a section of the journal

Frontiers in Pediatrics

Received: 29 March 2020

Accepted: 09 April 2020

Published: 30 April 2020

Citation:

Passanisi S, Lombardo F, Salzano G and Pajno GB (2020) Are Children

Most of the Submerged Part of

SARS-CoV-2 Iceberg?

Front. Pediatr. 8:213.

doi: 10.3389/fped.2020.00213
Thus far, among the 14,381 subjects who died with SARS-CoV-2 in Italy, there was only one child (2). These data are in concordance with those reported from other European countries and a recent review of 72,314 COVID-19 patients by the Chinese Center for Disease Control and Prevention that revealed that there were $<1 \%$ of pediatric cases. Furthermore, among children younger than 10 years of age no deaths were reported (3). Even during the outbreak of severe acute respiratory syndrome coronavirus (SARS-CoV) and middle-east respiratory syndrome coronavirus (MERS-CoV) the rate of infected children was quite low (5-7\% and $2-3 \%$, respectively) $(4,5)$.

\section{SARS-CoV-2 INFECTION IN CHILDREN}

The most common symptoms in children with confirmed SARS-CoV-2 are fever, dry cough, pharyngeal erythema, and fatigue (6). Recently, Dong et al. described a cohort of 2,143 Chinese children with suspected or confirmed COVID-19. The authors reported that among symptomatic children, only $5 \%$ had dyspnoea or hypoxemia and $0.6 \%$ presented acute respiratory distress syndrome or multiorgan failure (7). Early laboratory markers that are typically associated to SARS-CoV-2 infection in adults such as lymphopenia, increased liver enzymes, anemia, increased inflammatory markers, are very rare in children (8).

The reasons why children appear to be less affected and if infected develop milder clinical pictures due to COVID-19 are still uncertain. Several hypothesis have been put forward. Children may have a more effective response against SARS-CoV-2 as their immune system may be strengthened by the recurrence of several viral infections toward which they tend in the first years of life. In addition, adults seem to have a more vigorous immune response that may lead to "cytokine storm" which will further deteriorate lung injury (9). This theory is supported by the rare increase of inflammatory markers in children with confirmed COVID-19, as reported above. Another interesting hypothesis is related to angiotensin-converting enzyme 2 (ACE2). This enzyme is widely expressed in organs, including lungs in which it seems to act in a protective manner especially against severe respiratory virus disease (10). The extracellular domain of ACE2 
has been demonstrated to be the functional receptor for the spike protein of SARS-CoV, and recently, of the SARS-CoV-2 (11). Experiments in rats show that the pulmonary renin angiotensin system undergoes an age-dependent imbalance toward a more pronounced inflammation and more severe lung injury (12). In fact, ACE2 expression was seen to significantly decrease with increasing age in rat lung models, with old male rats having the lowest levels (13). Therefore, a higher concentration of ACE2 in lung pneumocytes in children could explain the rarity of severe clinical manifestations due to SARS-CoV-2 infection. Other suggested reasons that may contribute include lack of smoking, less exposure to air pollution and fewer underlying chronic conditions in children rather than adults (14). However, further studies are awaited to better investigate the underlying mechanisms that lead to milder disease presentation in the pediatric population.

\section{DISCUSSION}

Although more than a million people have already had a confirmed diagnosis of SARS-CoV-2 worldwide, there is a strong impression that the true prevalence of SARS-CoV-2 infection is much higher. For instance, one study suggested that $86 \%$ of all early SARS-CoV-2 infections in China remained undiagnosed (15). Pharyngeal and nasal swabs, which represent the most used diagnostic investigations, are mostly reserved to those individuals who present severe illness. In addition, the sensitivity of these tests is not yet known, but numerous false negatives may occur, since the virus may have translocated from the upper to the lower airways. Therefore, people with confirmed diagnosis may only be the tip of the iceberg of

\section{REFERENCES}

1. Hui DS, Azhar EI, Madani TA, Ntoumi F, Kock R, Dar O, et al. The continuing 2019-nCoV epidemic threat of novel coronaviruses to global health - the latest 2019 novel coronavirus outbreak in Wuhan, China. Int J Infect Dis. (2020) 91:264-6. doi: 10.1016/j.ijid.2020. 01.009

2. Integrated Surveillance of COVID-19 in Italy. Available on line at: https:// www.epicentro.iss.it/en/coronavirus/bollettino/Infografica_5aprile\%20ENG. pdf (accessed April 5, 2020).

3. Wu Z, McGoogan JM. Characteristics of and important lessons from the coronavirus disease 2019 (COVID-19) outbreak in China: summary of a report of 72314 cases from the Chinese Center for Disease Control and Prevention. JAMA. (2020) 323:1239-42. doi: 10.1001/jama.2020. 2648

4. Wong GW, Li AM, Ng PC, Fok TF. Severe acute respiratory syndrome in children. Pediatr Pulmonol. (2003) 36:261-6. doi: 10.1002/ppul. 10367

5. Alhamlan FS, Majumder MS, Brownstein JS, Hawkins J, Al-Abdely HM, Alzahrani A, et al. Case characteristics among Middle East respiratory syndrome coronavirus outbreak and non-outbreak cases in Saudi Arabia from 2012 to 2015. BMJ Open. (2017) 7:e011865. doi: 10.1136/bmjopen-2016-011865

6. Hong H, Wang Y, Chung HT, Chen CJ. Clinical characteristics of novel coronavirus disease 2019 (COVID-19) in newborns, infants and children. Pediatr Neonatol. (2020) 61:131-2. doi: 10.1016/j.pedneo.2020. 03.001
SARS-CoV-2 pandemic. The majority of infected children do not undergo diagnostic investigations for COVID-19 as they are asymptomatic or mildly symptomatic. Available data indicate that children who become infected with SARS-CoV-2 may have more upper respiratory tract rather than lower respiratory tract involvement (7). This may explain the low rate of infected pediatric patients reported in epidemiological studies. Fecal shedding persists in the stool for several weeks after diagnosis (16). Extended shedding in nasal secretions and stool may have remarkable implications for community spread in kindergartens, schools, and at home (17). Therefore, the role of children in community-based viral transmission should be carefully investigated to understand how much it can actually affect public health.

In the meantime, several countries have issued strict governmental decrees prohibiting movement in public places except for justifiable work reasons, basic necessities (i.e., food shopping), and health emergencies. School closures were among the first measures which had been adopted. According to UNESCO monitoring, over 160 countries have implemented nationwide closures, impacting over $87 \%$ of world's student population. Together these hard interventions seem to give encouraging results (18): reducing the contagion among the pediatric population could be a first step to curb the spread of COVID-19.

\section{AUTHOR CONTRIBUTIONS}

SP drafted and wrote the paper. GS and FL contributed to the discussion. GP reviewed and approved the paper.

7. Dong Y, Mo X, Hu Y, Qi X, Jiang F, Jiang Z, et al. Epidemiological characteristics of 2143 pediatric patients with 2019 coronavirus disease in China. Pediatrics. (2020). doi: 10.1542/peds.2020-0702. [Epub ahead of print].

8. Ludvigsson JF. Systematic review of COVID-19 in children shows milder cases and a better prognosis than adults. Acta Paediatr. (2020). doi: 10.1111/apa.15270. [Epub ahead of print].

9. Buckley RH. "Immunology" in Nelson Textbook of Pediatrics. 19th ed. Philadelphia, PA: Elsevier (2013).

10. Gu H, Xie Z, Li T, Zhang S, Lai C, Zhu P, et al. Angiotensin-converting enzyme 2 inhibits lung injury induced by respiratory syncytial virus. Sci Rep. (2016) 6:19840. doi: 10.1038/srep19840

11. Batlle D, Wysocki J, Satchell K. Soluble angiotensin-converting enzyme 2: a potential approach for coronavirus infection therapy? Clin Sci. (2020) 134:543-5. doi: 10.1042/CS20200163

12. Schouten LR, Helmerhorst HJ, Wagenaar GT, Haltenhof T, Lutter R, Roelofs JJ, et al. Age-dependent changes in the pulmonary reninangiotensin system are associated with severity of lung injury in a model of acute lung injury in rats. Crit Care Med. (2016) 44:e122635. doi: 10.1097/CCM.0000000000002008

13. Xie X, Chen J, Wang X, Zhang F, Liu Y. Age- and gender-related difference of ACE2 expression in rat lung. Life Sci. (2006). 78:216671. doi: 10.1016/j.lfs.2006.09.028

14. Lee PI, Hu YL, Chen PY, Huang YC, Hsueh PR. Are children less susceptible to COVID-19? J Microbiol Immunol Infect. (2020). doi: 10.1016/j.jmii.2020.02.011. [Epub ahead of print].

15. Li R, Pei S, Chen B, Song Y, Zhang T, Yang W, et al. Substantial undocumented infection facilitates the rapid dissemination of novel 
coronavirus (SARS-CoV2). Science. (2020). doi: 10.1126/science.abb3221. [Epub ahead of print].

16. Cai J, Xu J, Lin D, Yang Z, Xu L, Qu Z, et al. A case series of children with 2019 novel coronavirus infection: clinical and epidemiological features. Clin Infect Dis. (2020) ciaa198. doi: 10.1093/cid/ciaa198

17. Cruz TA, Zeichner SL. COVID-19 in children: initial characterization of the pediatric disease. Pediatrics. (2020). doi: 10.1542/peds.2020-0834. [Epub ahead of print].

18. Flaxman S, Mishra S, Gandy A, Unwin HJT, Coupland H, Mellan TA, et al. Estimating the Number of Infections and the Impact of Non-pharmaceutical Interventions on COVID-19 in 11 European Countries. Imperial College London (2020). doi: 10.25561/77731
Conflict of Interest: The authors declare that the research was conducted in the absence of any commercial or financial relationships that could be construed as a potential conflict of interest.

Copyright $\odot 2020$ Passanisi, Lombardo, Salzano and Pajno. This is an open-access article distributed under the terms of the Creative Commons Attribution License (CC $B Y)$. The use, distribution or reproduction in other forums is permitted, provided the original author(s) and the copyright owner(s) are credited and that the original publication in this journal is cited, in accordance with accepted academic practice. No use, distribution or reproduction is permitted which does not comply with these terms. 